\title{
The Impact of the Rise Global Supply Chains on the New Tendencies in the Contemporary Foreign Trade Policy
}

\author{
Zdzisław W. Puślecki ${ }^{1}$ \\ ${ }^{1}$ Department of International Economy, Faculty of Political Science and Journalism, Adam Mickiewicz \\ University, Poznań \\ Correspondence: Zdzisław W. Puślecki, ul. Umultowska 89 A, 61-614 Poznań, Poland. Tel: 48-61-829-6568.
}

Received: January 9, 2018

Accepted: January 25, $2018 \quad$ Online Published: February 20, 2018

doi:10.20849/iref.v2i1.310

URL: https://doi.org/10.20849/iref.v2i1.310

Paper prepared in the framework of the Grant OPUS, Narodowe Centrum Nauki -NCN (National Centre of Science - NCS), Nr UMO - 2013/11/B/HS5/03572

\begin{abstract}
The main aim of the article is indication of impact of the rise global supply chains on the new tendencies in contemporary foreign trade policy. The subject of the discussion and theoretical contribution in the undertaken research program is presents new tendencies in international trade - the rise of global supply chains, the impact of the rise global supply chains on the political economy of trade and countries motivations for cooperating on trade policies and the rise of global supply chains and increasing importance of bilateral agreements in the foreign trade policy. It is important to underline that a few multinational firms are responsible for a major share of world trade and for the rise of global supply chains. On the one hand, these firms should support regulatory harmonization across different Preferential Trade Agreements (PTAs) in order to lower trade costs. On the other hand, they might also resist harmonization - and encourage certain non-tariff measures - in order to prevent new competitors from entering markets. This may partly explain the persistence of regulatory divergence, and suggests that the political economy of regulatory convergence, especially in the conditions of the rise global supply chains, may be more important and more complex than is sometimes suggested.
\end{abstract}

Keywords: foreign trade policy, global supply chains, new tendencies, cooperating on trade policies, bilateral trade policy

\section{Introduction}

International trade during the rise of global supply chains interfaces with many other policy areas, such as macroeconomic policy, intellectual property, environmental protection, health and employment. In some of these policy areas, there are well-developed multilateral regimes, while in other areas multilateral cooperation is more incipient and institutional frameworks are less developed. The fragmented, decentralized and non-hierarchical nature of the international trade system makes the pursuit of coherence particularly challenging, fragmentation has the advantage of allowing for experimentation as different policies can be tested at the bilateral, regional and multilateral levels. A number of institutions and policy processes are in place to enforce better surveillance of exchange rates and reduce global imbalances. However, in the time of the rise of global supply chains the question arises as to whether these will be used to set up a more cooperative system of exchange rates at the international level, and what role the World Trade Organisation (WTO) will play in this system.

There are a growing number of WTO disputes involving measures relating to environmental goods or policies. The challenge of securing agreement is made more acute by the need to resolve difficult questions during the rise of global supply chains about the effectiveness of different policies and their impact on trading partners, the answers to which depend on a number of factors, such as the technology involved, the characteristics of the sector and the markets at issue.

Under a model of multilateral level governance, which was originally developed in the context of European integration, policy-making can take place at many different levels (international, national and various sub-national levels) and involve diverse actors (including non-state actors). While these additional layers of governance - and the resulting policy dispersion - can better target policies and encourage policy experimentation, they can also make coordination more difficult. This policy will have also an impact on international trade especially during the rise of global supply chains. Without some kind of agreement at the 
multilateral level, the trade impact of these national or domestic measures is likely to lead to frictions between WTO members and may eventually result in formal disputes being brought to the WTO.

\section{Materials and Methods}

Methodologically inclusive account breaks new ground in the new political economy models on contemporary foreign trade policy. The article presents new tendencies in the international trade, the impact of the rise global supply chains on the political economy of trade, countries motivations for cooperating on trade policies and the increasing importance of bilateral agreements in the foreign trade policy. The general theoretical approach will be of broad interest to economists interested in international and institutional questions as well as to political scientists. The main method applied in this research was a method of scientific study. It was used the institutional method, the comparative method, and the documentation method. It were applied also the descriptive method. Additionally, it used the methods of deductive and inductive forecasting.

\section{Discussion}

\subsection{New Tendencies in Contemporary Foreign Trade Policy}

Countries and producers increasingly specialize in certain stages of production depending on their particular comparative advantage (Krist, 2013; Jackson, 2013). It is importance and magnitude of this development for foreign trade policy. It is also important to underline that transport and energy costs, for instance, are reasons why supply chains remain more regional than global. Krugman (1991) brings increasing returns together with capital and labor migration and transport costs into one model. Krugman's (1991) model has become a workhorse of economic geography and international trade. The model is too complex to explain here but the reasons for that complexity are clear to see-when everything becomes "endogenous" small initial differences can make for big effects. To minimize transport costs, for example, firms want to locate near consumers but consumers want to locate near work. Thus, there are multiple equilibria and at a tipping point the location decisions of a single firm or consumer can snowball into big effects. A related trend also is the new form of regionalism that is sometimes referred as integration process development (Baldwin, 2012).

The differences among firms involved in trade are also important for the future development. The picture that arises from the trade literature and the data is that even if many firms are indirectly involved in trade-related activities, only relatively few are exporting or developed economies. Developing economies are importing and these firms tend to be larger and more productive than others (Figure 1, Figure2, and Table 1). Such firms also have a role in technology advancement and in the diffusion of know-how through supply chains.

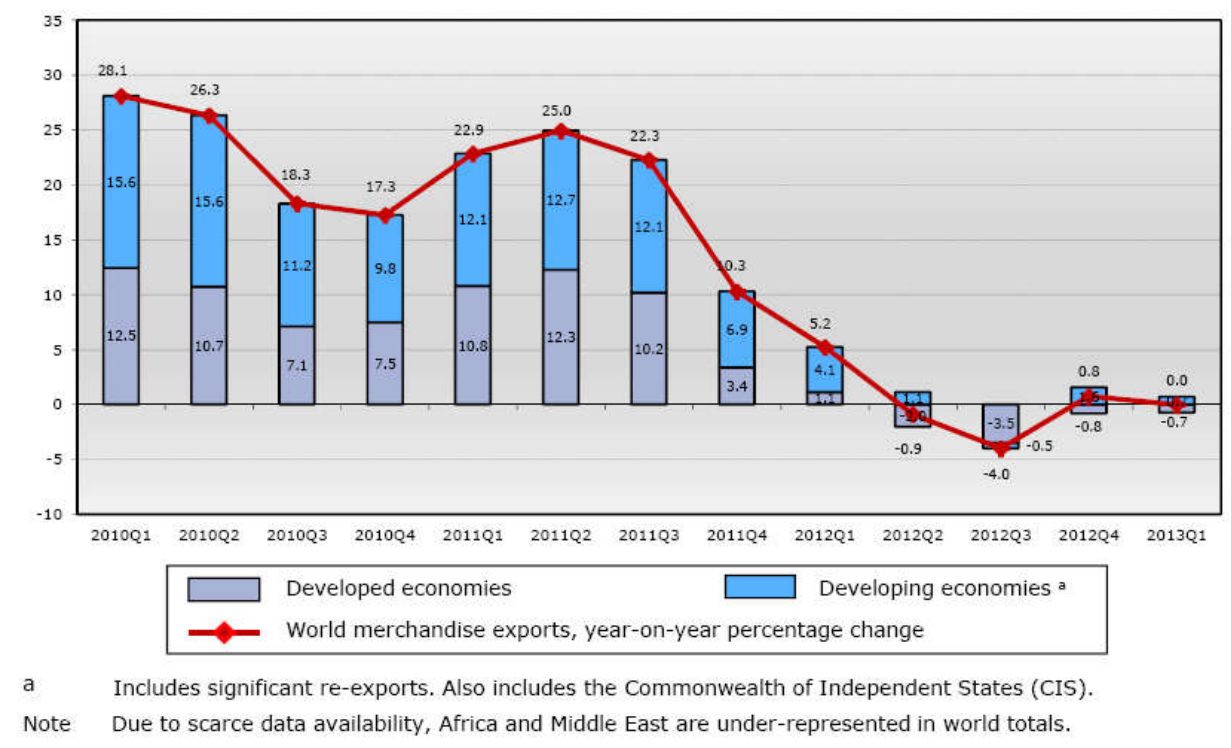

Figure 1. Contributions to year-on-year growth in world merchandise exports, 2010Q1-2013Q1 (percentage change in US\$ values)

Source: WTO Secretariat estimates, based on data compiled from IMF International Financial Statistics; Eurostat Comext Database; Global Trade Atlas; and national statistics. WTO Secretariat 2013. 

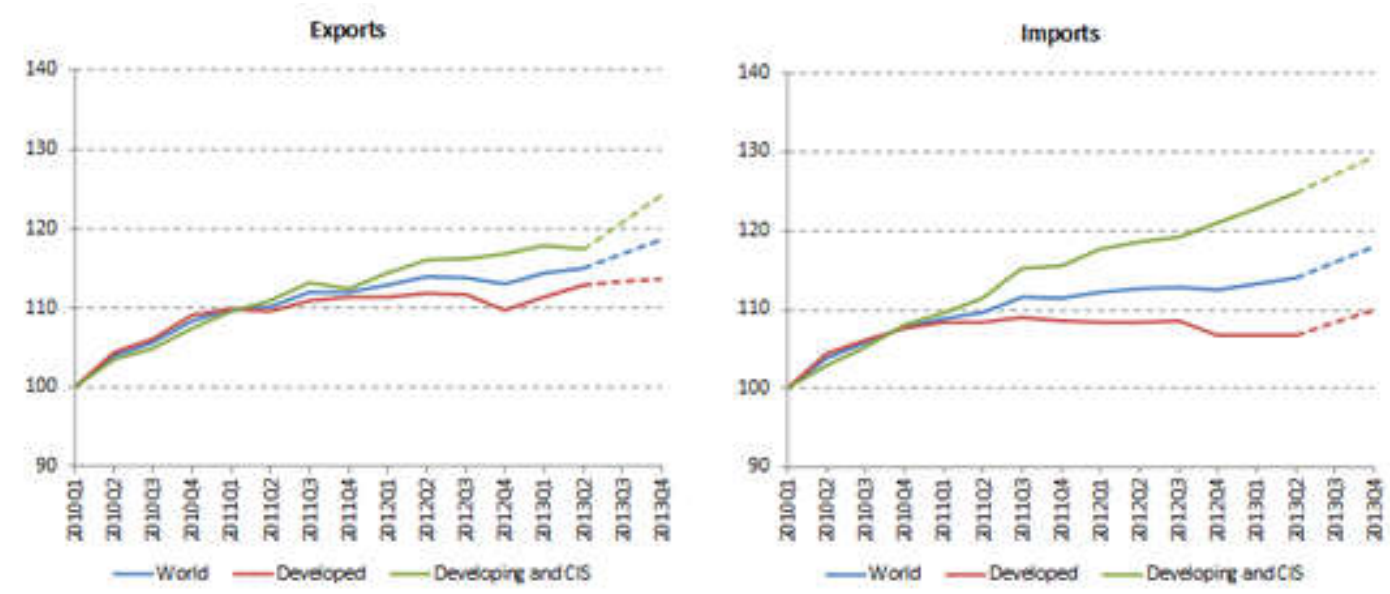

Figure 2. World merchandise trade volume by level of development, 2010Q1-2013Q4 ${ }^{\mathrm{a}}$

Seasonally adjusted indices, $2005 \mathrm{Q} 1=100$

${ }^{a}$ Figures for 2013Q3 and 2013Q4 are projections.

Source: WTO Secretariat. http://www.wto.org/english/news_e/pres13_e/pr694_e.htm 24.10.2013

Table 1. World merchandise trade and GDP, 2009-2014 a (annual \% change)

\begin{tabular}{|c|c|c|c|c|c|c|}
\hline & 2009 & 2010 & 2011 & 2012 & $2013 P$ & $2014 \mathrm{P}$ \\
\hline Volume of world merchandise trade & -12.5 & 13.8 & 5.4 & 2.3 & 2.5 & 4.5 \\
\hline \multicolumn{7}{|l|}{ Exports } \\
\hline Developed economies & -15.2 & 13.3 & 5.1 & 1.1 & 1.5 & 2.8 \\
\hline Developing economies and CIS & -7.8 & 15.0 & 5.9 & 3.8 & 3.6 & 6.3 \\
\hline \multicolumn{7}{|l|}{ Imports } \\
\hline Developed economies & -14.3 & 10.7 & 3.2 & 0.0 & -0.1 & 3.2 \\
\hline Developing economies and CIS & -10.6 & 18.2 & 8.1 & 4,9 & 5.8 & 6.2 \\
\hline Real GDP at market exchange rates. & -2.4 & 3.8 & 2.4 & 2.0 & 2.0 & 2.6 \\
\hline Developed economies & -3.8 & 2.7 & 1.5 & 1.2 & 1.2 & 1.9 \\
\hline Developing economies and CIS & 2.1 & 7.4 & 5.5 & 4.7 & 4.5 & 4.9 \\
\hline
\end{tabular}

${ }^{\text {a }}$ Figures for 2013 and 2014 are projections.

${ }^{\mathrm{b}}$ Average of exports and imports.

Source: WTO Secretariat for trade, consensus estimates of economic forecasters for GDP. http://www.wto.org/english/news_e/pres13_e/pr694_e.htm 24.10.2013

The demand for imports in developing economies is reviving but at a slower rate than expected. This hindered growth of exports from both developed and developing countries in the first half of 2013 and 2014 was the reason for the lower forecasts. Although the trade slowdown was mostly caused by adverse macro-economic shocks, there are strong indications that protectionism has also played a part and is now taking new forms which are harder to detect. Negotiations under way in the framework of the WTO can address these problems, facilitating greater trade and opportunities to spur economic growth. Some short-term prospects are improving with encouraging data coming from Europe, the US, Japan and China. Reports on private sector activities from purchasing managers (purchasing managers' indices, which give some indication about future activity), shipping rates, automobile production and other leading indicators, suggest that the economic slowdown has bottomed out and that a tentative recovery is underway.

Trends in the composition of trade shows that trade in services has grown faster than trade in goods over the last 
two decades (Krist, 2013). In this context important is how advances in information and communication technology have enabled a rapid expansion of services trade (Jackson, 2013). This trend might in the future be spurred by rising energy costs. Moreover, the share of services in both manufacturing firms' inputs and outputs has increased. Digitalization and 3D printing are examples of the increasing grey zone between goods and services. Whether they are classified as one or the other is significant as different regulatory regimes might apply. With regard to natural resources, it shows that their price has increased and that the price of food products has become more volatile. Open question is how higher and more volatile agricultural commodity prices raise concerns regarding food security in developing countries (Eagleton-Pierce, 2013) and how this prices influence for the rise of global supply chains.

It can observe that comparable development has occurred in foreign direct investment. Inflows into developing countries and outflows from these countries now represent a major share of total foreign direct investment (FDI) (Jackson, 2013), and FDI between developing countries is rapidly expanding. Related to this development is the industrialization of developing countries and de-industrialization of developed countries which, once again, is closely interconnected with global supply chains. However, this growth is limited to only a few economies. It has caused greater differences among developing countries, with growing emerging economies and struggling least-developed countries (LDCs).

Distributional effects of trade play an important role in the broader socioeconomic context. It is important examines the extent to which the recent sharp increase in the unemployment rates of developed countries may be linked to trade and what this could mean for attitudes towards trade. While there is no conclusive evidence that trade contributes significantly to changes in long-run unemployment or in income inequality, public concerns about current levels of unemployment and income distribution in a number of countries are likely to have a bearing on trade policy-making.

Another ongoing trend is the increasing importance of consumer concerns (regarding the environment or food safety, for example) which has led to a proliferation of public policy measures that affect trade (WTO, 2012b). Global supply chains might exacerbate the issue when large firms impose private standards throughout their respective supply chains. A further trend is the fierce competition for scarce natural.

\subsection{The Impact of the Rise Global Supply Chains on Countries Motivations for Cooperating on Trade Policies}

The industrialization and spectacular growth of emerging economies, together with the fast expansion of services trade and of FDI, are inextricably related to the next intensive growth of production. The focus here will be on how the rise of global supply chains has had an impact on the political economy of trade and countries motivations for cooperating on trade policies (Jones, 2015). There is both theory and evidence suggesting that participation in global supply chains tends to strengthen anti-protectionist forces (Jones, 2015). These forces have helped to drive some multilateral trade opening in the WTO (Jackson, 2013), both in specific sectoral as well as in broader accession-related negotiations. The main impact, however, has been on unilateral tariff reductions (mostly among developing countries), the proliferation of preferential trade agreements (PTAs) and bilateral investment treaties (WTO, 2011a; Krist, 2013; Jones, 2015; Deudney, 2014). A considerable amount of trade opening has thus taken place outside the WTO.

The internationalization of supply chains was very important for fast economic development and industrialization of developing countries. Before the emergence of supply chains - and the information and communication technology (ICT) revolution that underpinned it-industrialization involved building a strong industrial base often behind the protection of tariffs and other NTMs (Jupill, Mattli \& Snidal, 2013). The unbundling of global production made it possible for countries to industrialize by joining international supply chains (Jones, 2015). This process also changed the political economy of trade policy, creating in many developing countries a strong incentive to undertake unilateral tariff reductions.

There are three mechanisms through which production unbundling can lead to unilateral tariff reductions. First, the offshoring of production is likely to alter lobbying over trade policy in the host country. The relocation of production transforms importers of the products concerned into exporters. As a result, lobbying in favour of import tariffs on these goods decreases and pressure to reduce upstream tariffs increases. This effect, however, is more limited in cases where governments set up export processing zones to exploit the growing industrialization opportunities offered by supply chains (Jones, 2015). Secondly, a fall in coordination and communication costs may also have an impact on lobbying. With high trade costs, producers of final products may support infant industry protection of intermediate products if they believe that it could lower the price of domestically produced intermediate goods compared with imports. However, a fall in coordination and communication costs can break the coalition of interests behind high trade barriers, and lead downstream producers to lobby against tariffs on 
intermediate goods. Thirdly, offshoring improves the competitiveness of developed countries' products by reducing their costs, thus undermining import substitution strategies in developing countries (Jackson, 2013). Developing countries governments may either respond by lowering the tariffs on final goods, or, alternatively, by lowering upstream tariffs to improve the competitiveness of domestic final goods.

Empirical evidence seems to confirm that lobbying is indeed an important determinant of trade policy. In particular, there is evidence suggesting that supply chains can explain why the recent financial crisis did not lead to significant protectionism despite the fact that many countries had prudence in their applied tariffs, meaning they could raise them without violating their WTO commitments (Jones, 2015).

While unilateral tariff reductions have clearly been a positive step in the direction of more open trade, they may also have complicated multilateral, reciprocity based tariff reductions in the WTO. It must be underline that developing countries have already significantly reduced their applied tariffs, giving developed countries exporters less to fight for in multilateral negotiations (Jackson, 2013). Developed countries exporters also see less value in asking developing countries to commit to lower tariffs because they do not believe that developing countries governments have strong incentives to raise them (Jones, 2015).

It is interesting to underline that foreign investment may lead governments to unilaterally reduce tariffs, thereby lowering the incentive to exchange tariff reductions in the WTO. Existing theoretical work suggests that a government's optimal tariff decreases when its constituents hold an ownership stake in a foreign market, leaving it with less incentive to manipulate the terms of trade (Krist, 2013). Extending a terms of trade model of trade agreements to account for international ownership, shows that by eroding large countries' motives to improve terms of trade by raising tariffs, international ownership can also reduce their incentive to sign trade agreements. It must be emphasized that calculations of reciprocity in tariff negotiations should consider patterns of international ownership as well as trade flows.

Unilateral tariff reductions, in as much as they were not bound in the WTO, have tended to increase the level of prudence in developing countries' tariffs-i.e., the difference between the level at which tariffs are bound and the level at which they are applied - which has in turn complicated the Doha Development Agenda (DDA) non-agricultural market access negotiations (Jones, 2015). In the DDA's early days, discussion focused on the question of whether and how credit should be granted for autonomous trade opening (Mattoo \& Olarreaga, 2001). Even when WTO members gave one's consent to negotiate reductions of their bound, rather than applied, tariff rates, the underlying problem did not disappear but merely reappeared under a different guise. Members started arguing about the value of reductions of bound rates that do not imply equivalent reductions of the corresponding applied rate.

\subsection{Increasing Importance Bilateral Agreements in the Foreign Trade Policy}

The fact that governments respond to the internationalization of supply chains by signing deep integration agreements at the regional level is broadly consistent with the limited amount of theory available on this topic (WTO, 2012b; Jones, 2015). It is important to underline that, deep rather than shallow integration agreements and more individualized rules are needed to address the policy problems associated with the internationalization of supply chains (Antràs \& Staiger, 2012). Countries intensively involved in supply chain trade may find it increasingly difficult to rely on broad GATT/WTO principles alone to address their trade-related problems, and may turn to more narrowly focused PTAs to achieve the deep and customized bargains they need (Jones, 2015).

It is interesting explore the effect of proliferating deep regional agreements on coherence in international trade governance (Jackson, 2013). The WTO suggested that new international trade rules are being negotiated and decided outside the WTO where power differences are greater and where the principles of non-discrimination and reciprocity are absent. It also argued that PTAs are here to stay. Governments will need to ensure that regional agreements and the multilateral trading system are complementary and that multilateral disciplines minimize any negative effects from PTAs (Krist, 2013). While the available literature suggests that deep integration rules are often non-discriminatory-for instance, provisions in the services or competition policy areas are often extended to non-members - certain provisions in regional agreements can contain discriminatory aspects that clash with the multilateral trading system. It has been shown that PTAs which make it more difficult to apply contingency measures to PTA partners may divert protectionist measures towards non-members (Prusa $\&$ Teh, 2010).

Deep provisions can also have a number of adverse systemic effects. For example, the important effects of regional regulatory harmonization can make it more difficult to multilateralize rules. PTAs may not include third-party most-favoured nation (MFN) clauses, thus effectively discriminating against other countries. Developed countries exporters may view bilateral and regional rather than multilateral agreements as faster and 
easier routes for achieving their objectives, further weakening the principle of non-discrimination.

With regard to services supply chains, some argue that their growth creates an additional need to re-examine and modernize current rules for services trade, as these rules were designed for a world where services were exported as final products from national firms, not a world where multiple firms supply stages of services production from multiple locations. Recent research on how differences in firms have an impact on trade policies reveals a related concern. Ciuriak et al., (2011) point at another difference between deep integration at the regional and at the multilateral level. While heterogeneous firms trade models suggest that more importance should be granted to extensive than to intensive margin responses to trade opening, there is evidence suggesting that PTAs have positive effects at the intensive margin and negative effects at the extensive margin, whereas the opposite is true of opening in the multilateral context.

\section{Results and Findings}

During the rise of global supply chains the development of various firm models has made it possible to explore the effects of differences in firms on the political economy of trade. It must be underlined that trade opening has two opposing effects on domestic firms within the same industry. First, the cost of exporting decreases, which allows more firms to export and increases the sales of established exporters. Secondly, competition increases, which harms domestic firms. Which of these channels dominates for an individual firm depends on firm characteristics, such as size. As a result, lobbying competition arises not only between sectors but also within sectors in which some firms benefit and some lose due to trade. This effect might especially arise in the context of fixed costs because they rise entry costs and thereby shield existing producers or exporters from competition.

The least and most productive firms during the rise of global supply chains oppose more open trade when it comes to a reduction of NTMs because the competition effect outweighs the sales effect. It is the firms close to the export cut-off, i.e., those that just break even taking into account the costs of exporting, which benefit from trade opening and support it. This results we can use to explain a persistent feature of trade policy, namely the reluctance to accept opening trade in homogeneous goods and during the rise of a global supply chains. The emergence of supply chains exacerbates the issue and might weaken reciprocity in trade negotiations. It must be underline that as the largest firms are engaged in global production networks, they support NTMs to protect their foreign affiliates. The mechanism is similar to the one described above: multinational affiliates have fewer problems to overcome fixed exporting costs compared with less productive competitors.

\section{Conclusion}

The need for firms to organize their supply chains across different countries has led to a demand for regional agreements that cover more than preferential tariffs. The harmonization of standards and rules on investment, intellectual property and services has become a standard part of new trade agreements. The differences among firms involved in trade are also important for the future development. The picture that arises from the trade is that even if many firms are indirectly involved in trade-related activities, only relatively few are exporting or importing and these firms tend to be larger and more productive than others. Such firms also have a role in technology advancement and the diffusion of know-how through supply chains.

It must be underline that if trade during the rise of global supply chains is perceived by a majority of voters as causing unemployment and/or increasing inequality, governments could refrain from pursuing further trade opening and may even be tempted by protectionism. With regard to increased pressure for protectionism, there is some evidence that the WTO has played a significant role in recent years in preventing protectionist barriers. WTO rules and governments commitments, together with reinforced monitoring mechanisms, may account at least in part for the limited protectionist reactions to the crisis. One problem that may arise in the future is if governments turn to measures that are currently undisciplined or untested by WTO rules, pressure on the WTO to impose or apply disciplines in new areas and in the conditions of rise a global supply chains would increase, as is the case now with regard to exchange rate misalignments.

It must be emphasized that in the new WTO, the diverse membership must find common ground on new areas of negotiation especially in the conditions of the rise a global supply chains. The process of this negotiations must begin with domestic adjustment and development trade policies, and continue by harnessing all the available incentives, from RTAs to aid-for-trade, and by new forms of cooperation between developed, developing, and emerging countries like China, India, Brazil, Mexico, South Africa. The economic incentives for multilateral trade liberalization during the rise of global supply chains remain strong, and the new international economy of more broadly shared economic power represents a major victory for its success in the framework of the WTO multilateral trade system, but the power in the WTO has symbolic character. 


\section{References}

Antràs, P., \& Robert, W. S. (2012). Trade Agreements and the Nature of Price Determination. American Economic Review Papers and Proceedings, 102(3), 470-476. https://doi.org/10.1257/aer.102.3.470

Baldwin, R. (2012, December). WTO 2.0. Global governance of supply chain trade. Policy Insight, 64.

Ciuriak, D., B. Lapham, R. Wolfe, T. Collins-Williams, \& Curtis, J. M. (2011, November). Firms in International Trade: Towards a New Trade Policy.

Deudney, D. (2014). Hegemony, nuclear weapons, and liberal hegemony. In G. J. Ikenberry (Ed.), Power, Order, and Change in World Politics. Cambridge: Cambridge University Press. https://doi.org/10.1017/CBO9781139680738.011

Eagleton-Pierce Matthew. (2013). Symbolic Power in the World Trade Organization. Oxford: Oxford University Press.

IMF International Financial Statistics. (2013). Global Trade Information Services GTA database, national statistics. Retrieved from http://www.wto.org/english/news_e/pres13_e/pr694_e.htm 24.10.2013

Jackson, R. J. (2013). Global Politics in the $21^{\text {st }}$ Century. New York: Cambridge University Press.

Jones Kent. (2015). Reconstructing the World Trade Organization for $21^{\text {st }}$ Century: An Institutional Approach. Oxford, New York: Oxford University Press.

Jupill, W. Mattli, \& Snidal, D. (2013). Institutional Choice and Global Commerce. New York: Cambridge University Press. https://doi.org/10.1017/CBO9781139855990

Krist, W. (2013). Globalization and America's Trade Agreements. Baltimore: John Hopkins University Press.

Krugman, P. (1991). Increasing Returns and Economic Geography. Massachusetts Institute of Technology. https://doi.org/10.1086/261763

Kupchan Ch. A. (2014). Unpacking hegemony: the social foundations of hierarchical order. In G. J. Ikenberry (Ed.), Power, Order, and Change in World Politics. Cambridge: Cambridge University Press. https://doi.org/10.1017/CBO9781139680738.003

Mattoo, A., \& Olarreaga, M. (2001). Should Credit be Given for Autonomous Liberalization in Multilateral Trade Negotiation. CEPR Discussion Papers 2821.

Prusa, T. J., \& The, R. (2010). Protection Reduction and Diversion: PTAs and the Incidence of antidumping Disputes. NBER Working Papers 16276. https://doi.org/10.3386/w16276

WTO Secretariat. (2013). WTO Secretariat estimates, based on data compiled from IMF International Financial Statistics; Eurostat Comext Database; Global Trade Atlas; and national statistics.

WTO. (2011a). The 2011 World Trade Report.

WTO. (2011b). The 2011 World Trade Report.

WTO. (2013). The 2013 World TradeReport.

Copyright for this article is retained by the author(s), with first publication rights granted to the journal.

This is an open-access article distributed under the terms and conditions of the Creative Commons Attribution license (http://creativecommons.org/licenses/by/4.0/). 